\title{
Linguistic Validation of the Intermittent Self-catheterization Questionnaire for Patients With Neurogenic Bladder Who Perform Intermittent Catheterization for Voiding Dysfunction
}

\author{
Soon Ho Kang ${ }^{1}$, Seung-June $\mathrm{Oh}^{1}$, Seong Jin Jeong ${ }^{2}$, Sung Yong $\mathrm{Cho}^{1,3}$ \\ ${ }^{1}$ Department of Urology, Seoul National University Hospital, Seoul, Korea \\ ${ }^{2}$ Department of Urology, Seoul National University Bundang Hospital, Seongnam, Korea \\ ${ }^{3}$ Department of Urology, Seoul Metropolitan Government - Seoul National University Boramae Medical Center, Seoul, Korea
}

Purpose: In recent years, the importance of patient satisfaction and quality of life - referred to as patient-related outcomes has been emphasized, in addition to the evaluation of symptoms and severity through questionnaires. However, the questionnaires that can be applied to Korean patients with neurogenic bladder are limited. Therefore, the current study linguistically validated the Intermittent Self-Catheterization Questionnaire (ISC-Q) as an instrument to evaluate the quality of life of Korean patients with neurogenic bladder who regularly perform clean intermittent catheterization (CIC).

Methods: The validation process included permission for translation, forward translations, reconciliation, backward translation, cognitive debriefing, and proofreading. Two bilingual translators independently translated the original version of the ISCQ into Korean and then combined the initial translations. A third bilingual translator performed a backward translation of the reconciled version into English. Five Korean-speaking patients with neurogenic bladder carried out the cognitive debriefing. Results: During the forward translation process, the 24 questions of the ISC-Q were translated into 2 Korean versions. The terms used in each version were adjusted from the original version to use more conceptually equivalent expressions in Korean. During the backward translation process, several changes were involving substitutions of meaning. In the cognitive debriefing process, 5 patients were asked to complete the questionnaire. All patients agreed that the questionnaire explained their situation well.

Conclusions: This study presents a successful linguistic validation of the Korean version of the ISC-Q, which could be a useful tool for evaluating treatment satisfaction in patients with neurogenic bladder performing CIC regularly.

Keywords: Catheterization; Neurogenic urinary bladder; Urination

- Research Ethics: This study was approved by the Institutional Review Board of the Seoul Metropolitan Government - Seoul National University Boramae Medical Center (approval number: 26-2016-64).

- Conflict of Interest: SYC, a member of the Editorial Board of International Neurourology Journal, is the corresponding author of this article. However, he played no role whatsoever in the editorial evaluation of this article or the decision to publish it. No potential conflict of interest relevant to this article was reported.

Corresponding author: Sung Yong Cho (iD https://orcid.org/0000-0001-9271-6951 Department of Urology, Seoul National University Hospital, 101 Daehak-ro, Jongno-gu, Seoul, 03080, Korea

E-mail: moretry@yahoo.com / Tel: +82-2-2072-1491 / Fax: +82-2-742-4665

Submitted: November 27, 2018 / Accepted after revision: January 24, 2019
C) $\$$ This is an Open Access article distributed under the terms of the Creative Commons Attribution Non-Commercial License (http://creativecommons.org/licenses/by-nc/4.0/) which permits unrestricted non-commercial use, distribution, and reproduction in any medium, provided the original work is properly cited. 


\section{INTRODUCTION}

Patients with neurogenic bladder should be treated with appropriate behavioral therapy such as adequate water intake and restriction of caffeinated drinks to promote proper urination. Although medications such as alpha-blockers, anticholinergic agents, beta-3 agonists, and antidiuretic hormone are very common as therapies, these drugs are often not fully effective in achieving complete control of frequent lower urinary tract symptoms such as urinary frequency, urgency, and persistence. A large amount of residual urine and urinary tract infections are more common in patients with neurogenic bladder than in the general population, and neurogenic bladder patients are at a higher risk of kidney damage in the long term [1]. Therefore, to overcome the limitations of behavioral therapy and pharmacotherapy, a catheter can be used to perform clean intermittent catheterization (CIC), which regularly empties the bladder, at least 4-6 times a day.

To date, nelaton catheters, which are mainly composed of rubber, are most commonly used in patients with neurogenic bladder who need to perform self-catheterization because they are the cheapest and most affordable options. However, nelaton catheters are so weak that they are difficult to insert into the urethra. Additionally, it is difficult to store and transport them cleanly and smoothly, and they have disadvantages, such as an increased risk of urinary tract infections and urethral trauma that occurs during reuse [2]. To overcome these shortcomings, various types of catheters have been marketed. However, very few tools are available in Korea for evaluating patient satisfaction, ease of use, and quality of life when using these catheters. Therefore, doctors cannot objectively evaluate patients' perspectives about performing catheterization in the outpatient clinic.

In recent years, the importance of patient satisfaction and quality of life - referred to as patient-related outcomes - has been emphasized, in addition to the evaluation of symptoms and severity through questionnaires. However, the questionnaires that can be applied to Korean patients with neurogenic bladder are limited. Therefore, the current study linguistically validated the Intermittent Self-Catheterization Questionnaire (ISC-Q) as an instrument to evaluate the quality of life of patients with neurogenic bladder who regularly perform CIC.

\section{MATERIALS AND METHODS}

\section{Intermittent Self-Catheterization Questionnaire}

The ISC-Q is used to evaluate aspects of quality of life specific to the needs of individuals performing intermittent self-catheterization [3]. It focuses on 4 issues: ease of use, convenience, discreetness, and psychological well-being.

\section{Translation and Linguistic Validation}

The Institutional Review Board of Seoul Metropolitan Government - Seoul National University Boramae Medical Center approved this study (approval number: 26-2016-64). This procedure was conceptually the same as that of previous studies designed to obtain translated versions of other questionnaires in Korean. The linguistic validation of the ISC-Q consisted of forward translation, reconciliation, backward translation, cognitive debriefing, and proofreading [4,5]. Two different bilingual translators performed forward translations, and in the process of the first forward translation left comments on difficulty, meaning, and alternative options for translation. Then, in the backward translation, cases where words were differently translated were reconciled into one English word. Comments on difficulty, meaning, and alternative options for translation were reflected in the backward translation, cognitive debriefing, and proofreading process.

\section{Permission}

Acquisition of consent was received directly from the researcher who developed the ISC-Q.

\section{Forward Translation}

Two independent bilingual speakers each performed a standard translation and also translated expressions and meanings from the original questionnaire into conceptually equivalent Korean words.

\section{Reconciliation}

Two bilingual speakers compared their differences in translation, and agreed on the most relevant Korean words for the final forward translated Korean version.

\section{Backward Translation}

A third bilingual speaker performed a backward translation of the reconciled version of the Korean questionnaire into English. Afterwards, the 3 bilingual speakers met to discuss the differ- 
ences among the original questionnaire, the reconciled version of the forward translation of the questionnaire, and the backward translation of the questionnaire. During this process, some comments on difficult-to-understand phrases were made on the basis of comparing the original text and the translated questionnaire in English, and alternative options for translation were suggested.

\section{Cognitive Debriefing}

The final questionnaire was given to 5 patients with different backgrounds in terms of age, sex, pathology, and educational level. The questionnaire was evaluated as being understandable, difficult to understand, or meaningless. Survey interviews were performed to interpret each question in the questionnaire and to provide participants with an opportunity to indicate whether there were difficulties in understanding the questions or whether there were any confusing terms.

\section{Final Proofreading}

The final questionnaire was prepared considering not only the various grammatical constructions and forms, but also its utility for evaluating patients' status.

\section{RESULTS}

\section{Forward Translation and Reconciliation}

As shown in Table 1, the 24 questions of the ISC-Q were translated into Korean. The subject of the questionnaire (ISC-Q) was translated as ganheoljeok jagadonyo seolmunji. The word "intermittent" was translated as bijeonggi and ganheoljeok in translations 1 and 2, respectively. The panel agreed on ganheoljeok ("intermittent").

\section{Ease of use}

Question 1, "It is easy to prepare my catheter for use each time I need it" in the original version, was translated as naneun piryosi sayonghal su itdorok kateteoreul swipge junbihal su itda. The word "easy" was translated as yongi and swipge in translations 1 and 2, respectively. The panel agreed on swipge ("easy").

Question 2, "It is messy to prepare my catheter for use" in the original version, was translated as naneun kateteoreul sayonghal su itdorok junbihaneunge bokjapada. The word "messy" was translated as golchiapeuda ("troubled") in translation 1, and bokjapada ("complicated") in translation 2. The phrase "for use" was translated as piryosi and sayonghal su itdorok in translations
1 and 2, respectively. Finally, the panel agreed on bokjapada and sayonghal su itdorok.

Question 3, "It is easy to insert my catheter" in the original version, was translated as naneun kateteoreul sabipaneun ge swipda. The word "easy" was translated as eoryeopji anta and swipda in translations 1 and 2, respectively. The panel agreed on swipda.

Question 4, "I find inserting the catheter is uncomfortable sometimes" in the original version, was translated as naneun kateteo sabip si gakkeum bulpyeonhameul neukkinda.

Question 5, "The design of the catheter makes it easy to insert" in the original version, was translated as kateteoui dijaini sabipagie swipge doeeo itda.

Question 6, "The catheter is fiddly to use" in the original version, was translated as kateteoreul sayonghagie seonggasida. The word "fiddly" was translated as seonggasida by both translators.

Question 7, "The lubrication on the catheter makes it difficult to use" in the original version, was translated as kateteoui yunhwaraegeuro inhae sayonghagiga eoryeopda. The word "lubrication" was translated as yunhwal in translation 1, and yunhwaryu in translation 2. The panel agreed on yunhwaraek.

Question 8, "I feel confident in my ability to use my catheter" in the original version, was translated as naneun kateteoreul jal hwaryonghaneunde jasini itda.

\section{Convenience}

Question 9, "Storage of catheters at home is inconvenient" in the original version, was translated as jibeseo kateteoreul bogwanhagie bulpyeonhada.

Question 10, "Taking enough catheters for a weekend away is very inconvenient" in the original version, was translated as jumaldongan oechulsi kateteoreul chungbunhi gajyeoganeun geosi maeu bulpyeonhada.

Question 11, "Taking enough catheters for a 2-week holiday is very inconvenient" in the original version, was translated as 2 weeks hyugasi kateteoreul chungbunhi gajyeoganeun geosi maeu bulpyeonhada. The word "weekend" was translated as yeohaeng in translation 1, and as hyuga in translation 2. The panel agreed on hyuga.

Question 12, "Disposal of my catheter is inconvenient when away from home" in the original version, was translated as jip bakke inneun gyeongu kateteoreul pyegihaneun geosi bulpyeonhada. The phrase "when away from home" was translated as jibeul tteonasseul ttae and jip bakke inneun gyeongu in translations 1 and 2, respectively. The panel reconciled it as jip bakke 


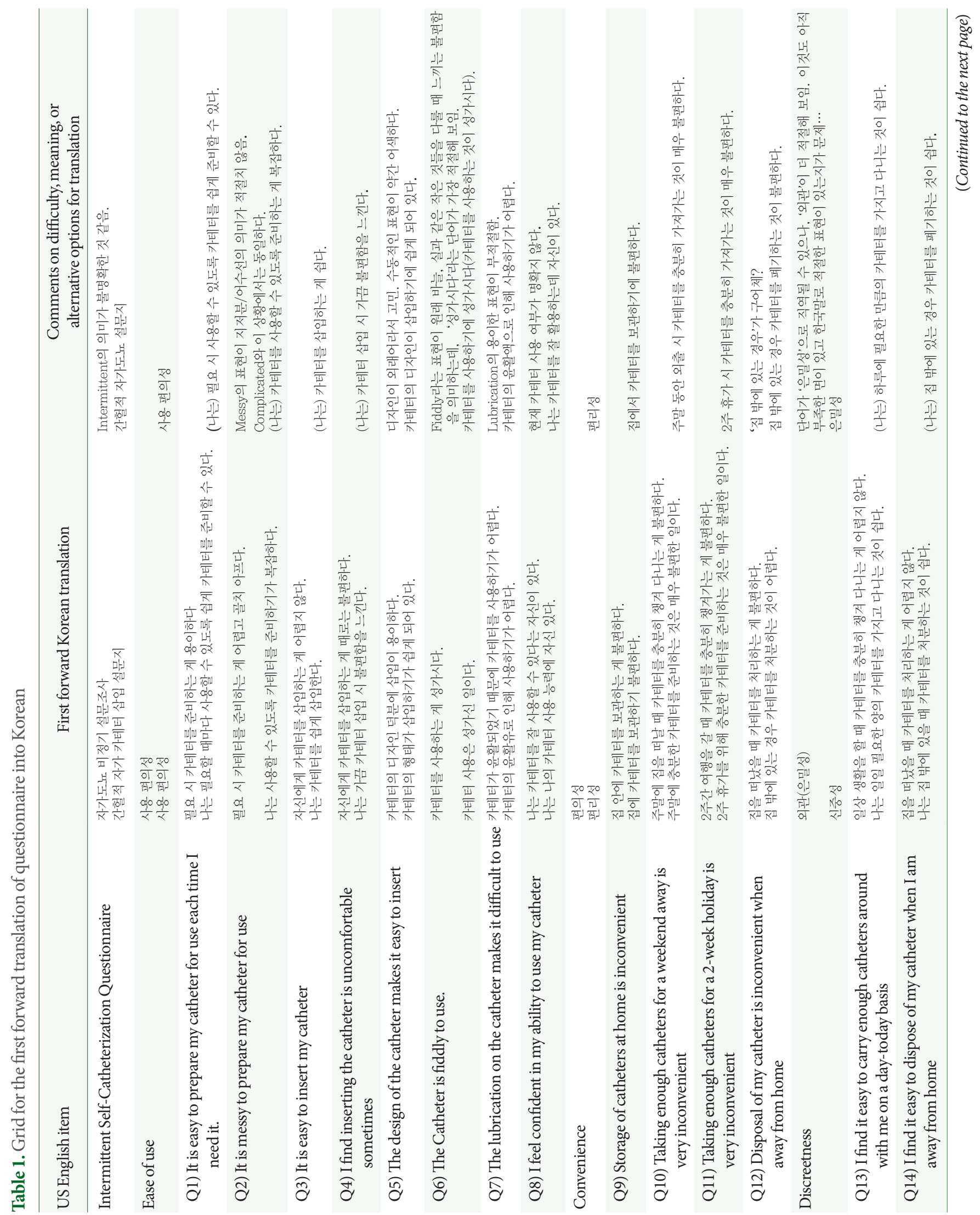




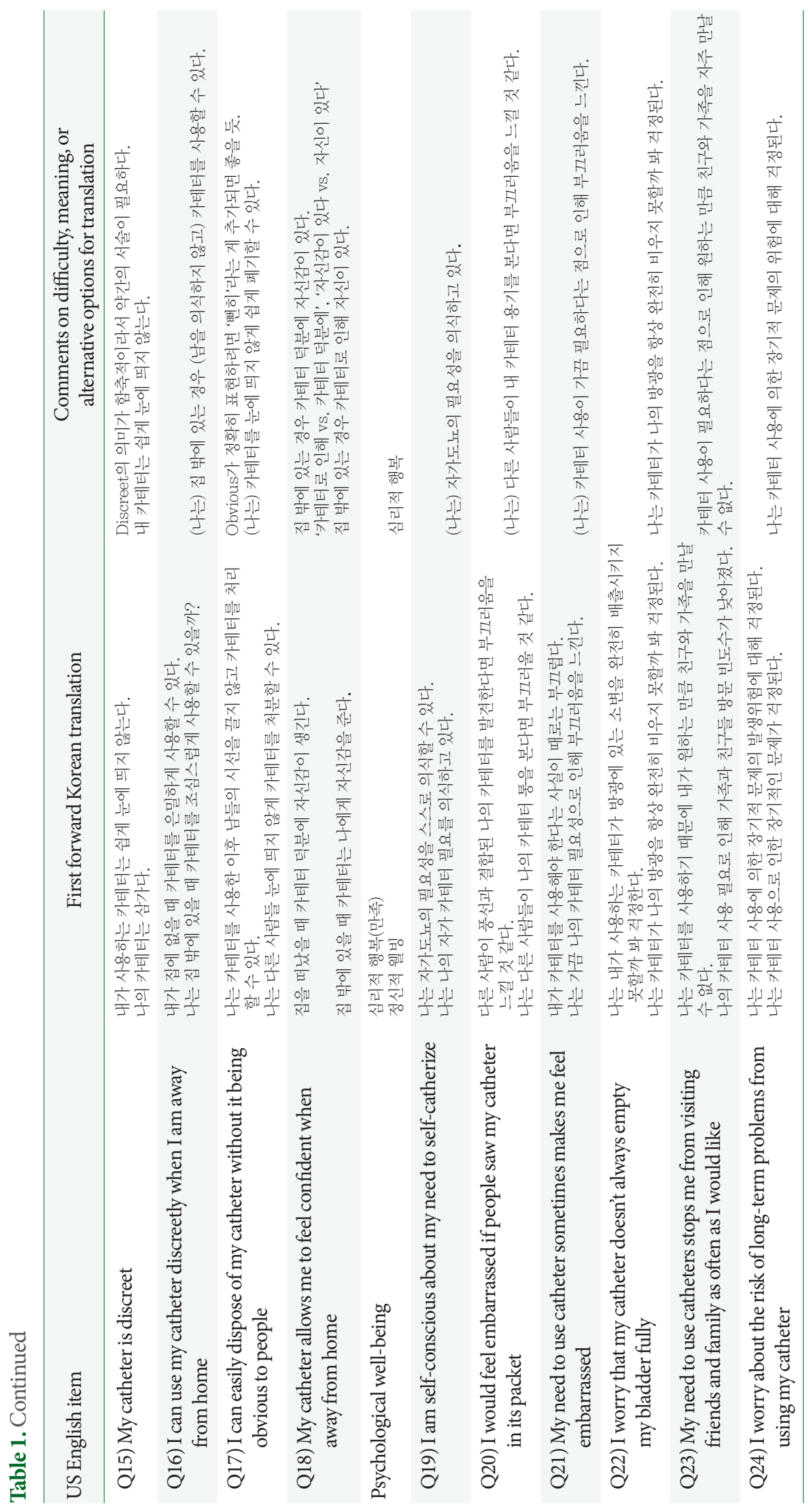


inneun gyeongu. The category of "discreetness" was translated as eunmilseong in translation 1, and as sinjungseong in translation 2. The panel agreed on eunmilseong.

\section{Discreetness}

Question 13, "I find it easy to carry enough catheters around with me on a day-to-day basis" in the original version, was translated as naneun harue piryohan mankeumui kateteoreul gajigo danineun geosi swipda.

Question 14, "I find it easy to dispose of my catheter when I am away from home" in the original version, was translated as naneun jip bakke inneun gyeongu kateteoreul pyegihaneun geosi swipda. The phrase "when I am away from home" was translated as jibeul tteonasseul ttae and jip bakke inneun gyeongu in translations 1 and 2, respectively. The panel reconciled it as jip bakke inneun gyeongu. The word "dispose" was translated as cheori in translation 1 , and as cheobun in translation 2 . The panel agreed on pyegi.

Question 15, "My catheter is discreet" in the original version, was translated as nae kateteoneun swipge nune ttuiji anneunda. The word "discreet" was translated as swipge nune ttuiji anneunda in translation 1 , and as samgada in translation 2 . The panel agreed on swipge nune ttuiji anneunda.

Question 16, "I can use my catheter discreetly when I am away from home" was translated as naneun jip bakke inneun gyeongu nameul uisikaji anko kateteoreul sayonghal su itda. The word "discreetly" was translated as eunmilhage in translation 1 , and as josimseureopge in translation 2. The panel agreed on nameul uisikaji anko.

Question 17, "I can easily dispose of my catheter without it being obvious to people" in the original version, was translated as naneun kateteoreul nune ttuiji anke swipge pyegihal su itda.

Question 18, "My catheter allows me to feel confident when away from home" in the original version, was translated as jip bakke inneun gyeongu kateteoro inhae jasini itda.

\section{Psychological well-being}

Question 19, "I am self-conscious about my need to self-catheterize" in the original version, was translated as naneun jagadonyoui piryoseongeul uisikago itda.

Question 20, "I would feel embarrassed if people saw my catheter in its packet" in the original version, was translated as naneun dareun saramdeuri nae kateteo yonggireul bondamyeon bukkeureoumeul neukkil geot gatda.

Question 21, "My need to use a catheter sometimes makes me feel embarrassed" in the original version, was translated as naneun kateteo sayongi gakkeum piryohadaneun jeomeuro inhae bukkeureoumeul neukkinda.

Question 22, "I worry that my catheter doesn't always empty my bladder fully" in the original version, was translated as naneun kateteoga naui banggwangeul hangsang wanjeonhi biuji motalkka bwa geokjeongdoenda. The word "empty" was translated as baechulsikida in translation 1, and as biuda in translation 2. The panel agreed on biuda.

Question 23, "My need to use catheters stops me from visiting friends and family as often as I would like" in the original version, was translated as kateteo sayongi piryohadaneun jeomeuro inhae wonhaneun mankeum chinguwa gajogeul jaju mannal su eopda. The phrase "my need to use catheters" was translated as naneun kateteoreul sayonghagi ttaemune and naui kateteo sayong piryoro inhae in translations 1 and 2, respectively. The panel agreed on kateteo sayongi piryohadaneun jeomeuro inhae.

Question 24, "I worry about the risk of long-term problems from using my catheter" in the original version, was translated as naneun kateteo sayonge uihan janggijeok munjeui wiheome daehae geokjeongdoenda.

\section{Backward Translation and Retranslation}

As shown in Table 2, the panel discussed the differences between translations of "the catheter is fiddly to use" in the original version and "it is bothersome to use the catheter" in the reconciled version. The panel finally agreed to change the translated term seonggasida in Korean to darugi himdeulda. The panel agreed to change the translated question kateteoui yunhwaraegeuro inhae sayonghagiga eoryeopda in Korean to kateotega yunhwaldoeeo sayonghagi eoryeopda.

For the category of "discreetness," the panel ultimately agreed to change the translated term eunmilseong to bunbyeolseong. The panel discussed the differences between "I find it easy to dispose of my catheter when I am away from home" in the original version and "it is easy (for me) to dispose the catheter when I'm outside the house" in the reconciled version. The panel commented on whether or not it would be suitable to change jip bakke inneun gyeongu ("when away from home") to oechulsi ("when I'm outside the house"). The panel finally agreed to change the term. The panel agreed to change the translated question nae kateteoneun swipge nune ttuiji anneunda to kateteoneun taineul uisikaji anko manjokseureopge sayongdoelman hada. The panel discussed the differences between "I can use my catheter discreetly when I am away from home" in 


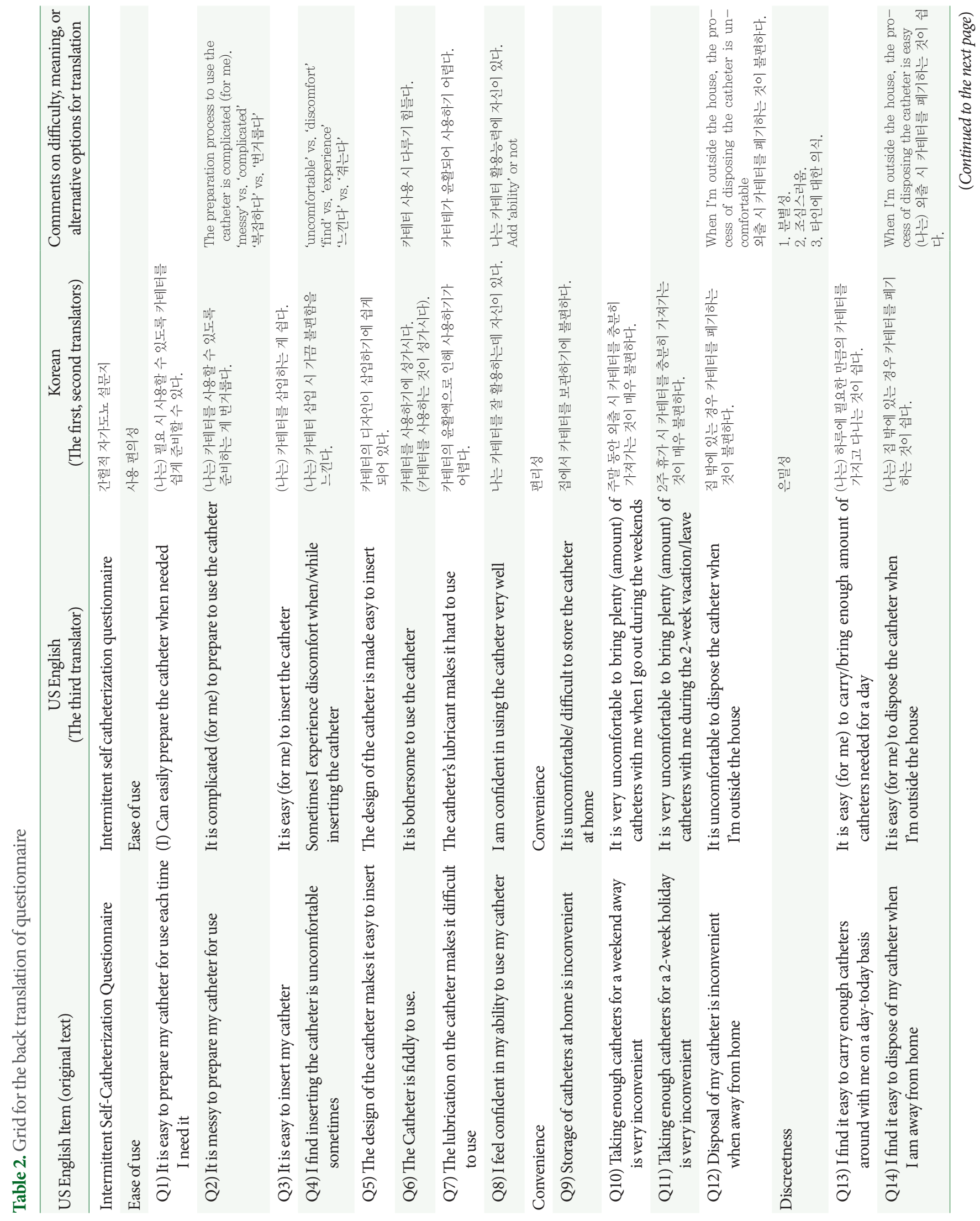




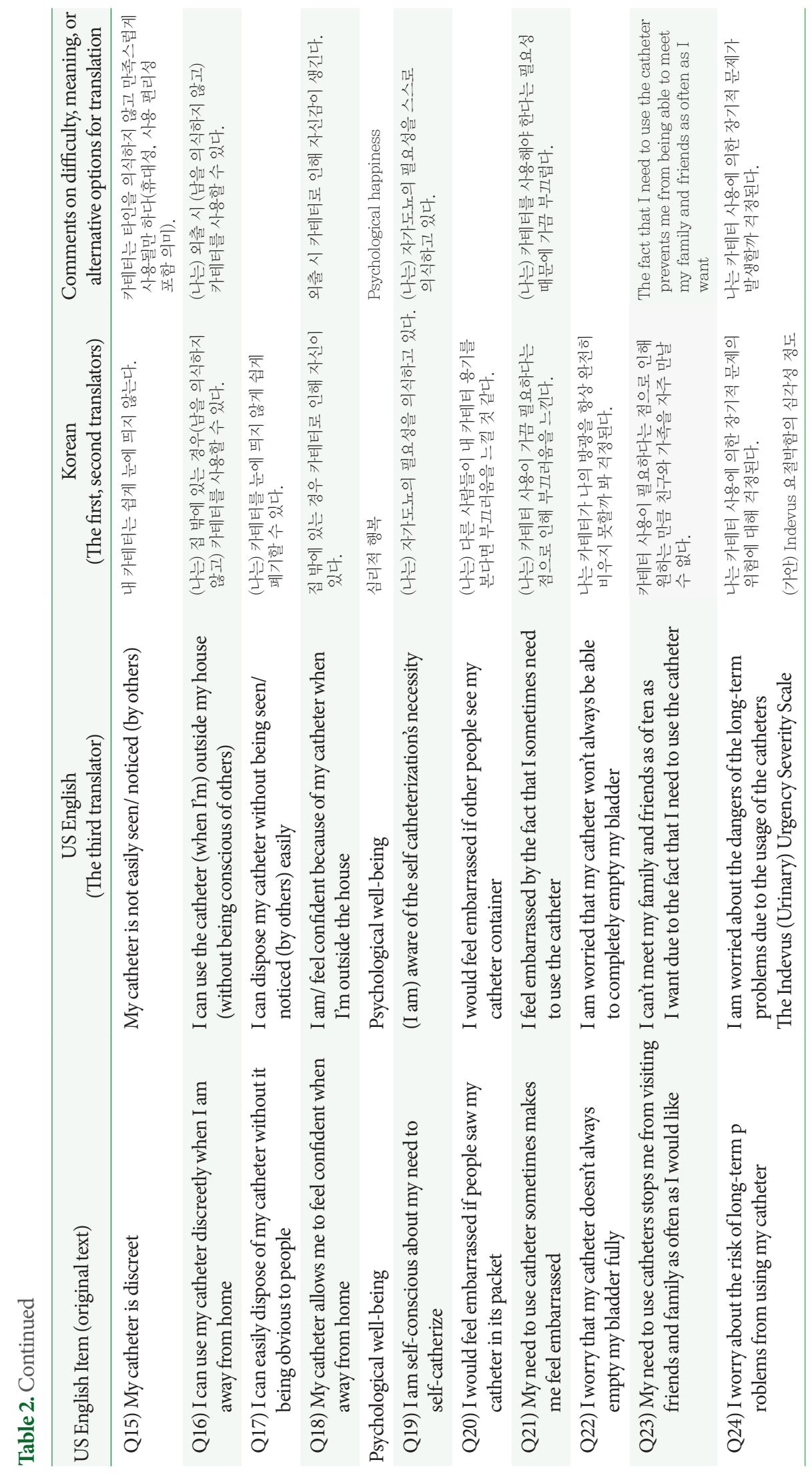


Table 3. Patient data summary sheet

\begin{tabular}{|c|c|c|c|c|c|}
\hline Subject & Age (yr) & Sex & $\begin{array}{c}\text { Pathology } \\
\text { (stress/urge/mixed) }\end{array}$ & $\begin{array}{c}\text { Profession/ } \\
\text { educational level }\end{array}$ & $\begin{array}{l}\text { Time to complete } \\
\text { questionnaire (min) }\end{array}$ \\
\hline 1 & 60 & $\mathrm{M}$ & Parkinsonism & High school & 8 \\
\hline 2 & 70 & $\mathrm{M}$ & Spinal cord injury & Elementary school & 15 \\
\hline 3 & 70 & $\mathrm{~F}$ & Spinal cord injury & Elementary school & 15 \\
\hline 4 & 45 & $\mathrm{~F}$ & Transverse myelitis & Middle school & 10 \\
\hline 5 & 53 & $\mathrm{~F}$ & Radiation cystitis & Middle school & 15 \\
\hline
\end{tabular}

\section{간헐적 자가도뇨 설문지 (ISC-Q)}

\begin{tabular}{|c|c|c|c|c|c|c|}
\hline & $\begin{array}{c}\text { 지극히 } \\
\text { 동의하지 않음 }\end{array}$ & \begin{tabular}{|c|} 
약간 \\
동의하지 않음
\end{tabular} & 의견 없음 & 약간 동의함 & 지극히 동의함 & $\begin{array}{c}\text { 바닥효과 } \\
\text { (Floor effect) }\end{array}$ \\
\hline \multicolumn{7}{|l|}{ 사용 편의성 } \\
\hline \multicolumn{7}{|l|}{ 1. (나는) 필요시 소변줄 (카테터)를 쉽게 준비할 수 있다. } \\
\hline \multicolumn{7}{|l|}{ 2. (나는) 소변줄을 사용할 수 있도록 준비하는게 번거롭다. } \\
\hline \multicolumn{7}{|l|}{ 3. (나는) 소변줄을 삽입하는게 쉽다. } \\
\hline \multicolumn{7}{|l|}{ 4. (나는) 소변줄 삽입 시 가끔 불편함을 느낀다. } \\
\hline \multicolumn{7}{|l|}{ 5. 소변줄의 디자인이 삽입하기에 쉽게 되어 있다. } \\
\hline \multicolumn{7}{|l|}{ 6. 소변줄 사용 시 다루기 힘들다. } \\
\hline \multicolumn{7}{|l|}{ 7. 소변줄이 윤활되어 (미끄러워) 사용하기 어렵다. } \\
\hline \multicolumn{7}{|l|}{ 8. 나는 소변줄을 활용하는데 자신이 있다. } \\
\hline \multicolumn{7}{|l|}{ 편리성 } \\
\hline \multicolumn{7}{|l|}{ 9. 집에서 소변줄을 보관하기에 불편하다. } \\
\hline \multicolumn{7}{|l|}{ 10. 주말동안 소변줄을 외출시 충분히 가져가는 것이 매우 불편하다. } \\
\hline \multicolumn{7}{|l|}{ 11. 소변줄을 2 주 휴가시 충분히 가져가는 것이 매우 불편하다. } \\
\hline \multicolumn{7}{|l|}{ 12. 소변줄을 집 밖에 있는 경우 폐기하는 것이 불편하다. } \\
\hline \multicolumn{7}{|l|}{ 분별성 } \\
\hline \multicolumn{7}{|l|}{ 13. (나는) 소변줄을 하루에 필요한 만큼 가지고 다니는 것이 쉽다. } \\
\hline \multicolumn{7}{|l|}{ 14. (나는) 외출 시 소변줄을 폐기하는 것이 쉽다. } \\
\hline \multicolumn{7}{|l|}{ 15. 소변줄은 타인을 의식하지 않고 만족스럽게 사용할만 하다. } \\
\hline \multicolumn{7}{|l|}{ 16. (나는) 외출 시 (타인을 의식하지 않고) 소변줄을 사용할 수 있다. } \\
\hline \multicolumn{7}{|l|}{ 17. (나는) 소변줄을 눈에 띄지 않게 쉽게 폐기 할 수 있다. } \\
\hline \multicolumn{7}{|l|}{ 18. 소변줄로 인해 외출 시 자신감이 생긴다. } \\
\hline \multicolumn{7}{|l|}{ 심리적 행복 } \\
\hline \multicolumn{7}{|l|}{ 19. (나는) 자가도뇨의 필요성을 스스로 알고 있다. } \\
\hline \multicolumn{7}{|l|}{ 20. (나는) 다른 사람들이 내 소변줄 용기통을 본다면 부끄러울 것 같다. } \\
\hline \multicolumn{7}{|l|}{ 21. (나는) 소변줄을 사용해야 한다는 필요성 때문에 가끔 부끄럽다. } \\
\hline \multicolumn{7}{|l|}{ 22. (나는) 소변줄이 나의 방광을 완전히 비우지 못할까 봐 항상 걱정된다. } \\
\hline \multicolumn{7}{|c|}{ 23. 소변줄을 사용해야 하기 때문에 원하는 만큼 친구와 가족을 자주 만날 수 없다. } \\
\hline 24. (나는) 소변줄을 사용함으로써 장기적 문제가 발생할까 걱정된다. & & & & & & \\
\hline
\end{tabular}

Fig. 1. Korean version of the Intermittent Self-Catheterization Questionnaire (ISC-Q). 
the original version and "I can use the catheter (when I'm) outside my house (without being conscious of others)" in the reconciled version. The panel commented on whether or not it would be suitable to change jip bakke inneun gyeongu ("when away from home") to oechulsi ("when I'm outside the house"). The panel agreed to change the translated question jip bakke inneun gyeongu kateteoro inhae jasini itda to oechul si kateteoro inhae jasingami saengginda. The panel agreed to change the translated question naneun kateteo sayongi gakkeum piryohadaneun jeomeuro inhae bukkeureoumeul neukkinda to naneun kateteoreul sayonghaeya handaneun piryoseong ttaemune gakkeum bukkeureopda. The panel also agreed to change the translated question naneun kateteo sayonge uihan janggijeok munjeui wiheome daehae geokjeongdoenda to naneun kateteo sayonge uihan janggijeok munjega balsaenghalkka geokjeongdoenda.

\section{Cognitive Debriefing and Proofreading}

The translated questionnaire was tested by 5 patients with neurogenic bladder who regularly performed CIC. As shown in Table 3, age, pathology, level of education, and time to complete the questionnaire varied across all 5 patients. The patients aged 70 years or older were not able to answer the questionnaire correctly, and the time required for the questionnaire ranged from 10 to 15 minutes. A 60 -year-old male patient did not know the meaning of "catheter," so he used his cell phone to search for the meaning of that word in the questionnaire. When asked whether the questionnaire explained the situation of the patient well, all the patients answered "yes." In addition, the format of the questionnaire was not particularly inconvenient for all patients. The final version is shown in Fig. 1.

\section{DISCUSSION}

Reviewing some words that had comments in the translation process, the word "messy" in question 2 was changed to "complicated" when translating into Korean because the meaning of "dirty, clutter" was inappropriate. As a result, it was translated as "complicated" in the backward translation process.

For question 5, the opinion was raised that the word for 'design' was difficult to translate into Korean because the word for "design" is a loanword in Korea, and it was felt that the passive expression was a bit awkward. However, it was backward-translated as "design," and therefore the panelists agreed to use the word "design" as a loanword.

The expression "fiddly" from question 6 was reconciled and backward-translated to "bothersome" because it refers to inconveniences when dealing with small objects, such as a needle and thread. Furthermore, in question 15, the meaning of "discreet" was implicative, so the decision was made that some further description was needed, and the expression was changed to "not easily noticeable." As a result, it was backward-translated into "not easily seen/noticed (by others)."

In conclusion, this present study presents the successful linguistic validation of the Korean version of the ISC-Q. The Korean version of the ISC-Q will play an important role in assessing the quality of life and the satisfaction of Koreans who are performing CIC, and it will serve as a tool that allows physicians to objectively evaluate patients who are performing CIC.

\section{ACKNOWLEDGEMENTS}

This article was supported by the members of the Questionnaire Investigation Committee of the Korean Continence Society: Ha Na Lee (Seoul Metropolitan Seonam Hospital), Ji Yun Chae (Mizlove Female Urology Clinic), Hyo Serk Lee (Cheil General Hospital \& Women's Healthcare Center), Min Soo Choo (Hallym University Dongtan Sacred Heart Hospital), Min Gu Park (Inje University Seoul Paik Hospital), and Seo Yeon Lee (Myongji Hospital).

\section{AUTHOR CONTRIBUTION STATEMENT}

- Full access to all the data in the study and takes responsibility for the integrity of the data and the accuracy of the data analysis: SHK, SJO, SJJ, SYC

- Study concept and design: SHK, SJO, SJJ, SYC

- Acquisition of data: $S H K$, SYC

- Analysis and interpretation of data: $S H K, S Y C$

- Drafting of the manuscript: $S H K, S Y C$

- Critical revision of the manuscript for important intellectual content: SHK, SYC

- Statistical analysis: SHK, SYC

- Obtained funding: SHK, SYC

- Administrative, technical, or material support: SHK, SYC

- Study supervision: SHK, SYC

\section{REFERENCES}

1. Nseyo U, Santiago-Lastra Y. Long-term complications of the neurogenic bladder. Urol Clin North Am 2017;44:355-66. 
2. Cobussen-Boekhorst H, Hermeling E, Heesakkers J, van Gaal B. Patients' experience with intermittent catheterisation in everyday life. J Clin Nurs 2016;25:1253-61.

3. Pinder B, Lloyd AJ, Elwick H, Denys P, Marley J, Bonniaud V. Development and psychometric validation of the intermittent selfcatheterization questionnaire. Clin Ther 2012;34:2302-13.

4. Cho SY, Lee HE, Jeong SJ, Oh SJ. Translation and linguistic validation of the Korean version of the "Benefit, Satisfaction, and Will- ingness to Continue" questionnaire for patients with overactive bladder. Int Neurourol J 2016;20:255-9.

5. Lee HN, Chae JY, Lee HS, Choo MS, Park MG, Lee SY, et al. Translation and linguistic validation of the Korean version of the treatment satisfaction visual analogue scale and the overactive bladder satisfaction with treatment questionnaire. Int Neurourol J 2017;21: 309-19. 